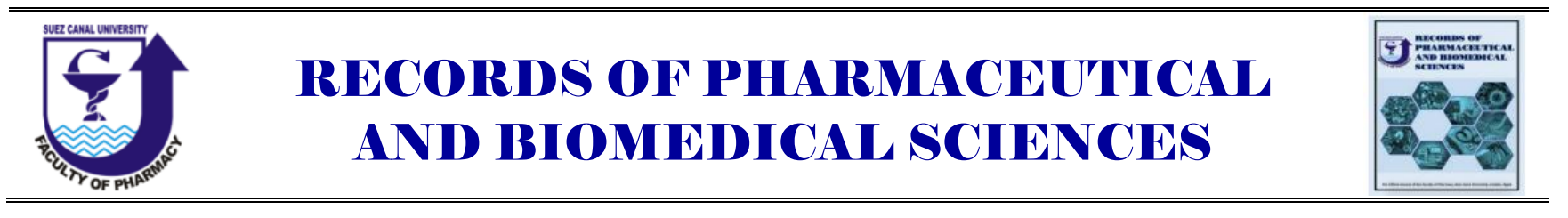

\title{
Enhancement of Growth and Alkaloids Accumulation in Hyoscyamus muticus L. Callus Cultures by High Salt Concentration
}

\author{
Eman Abdelrazik $^{a^{*}}$, Mohamed A. El-hamahmy ${ }^{\mathrm{b}}$, Enas E. Eltamany ${ }^{\mathrm{c}}$, Islam H. Abo-Elsoud ${ }^{\mathrm{d}}$, Elham M. \\ Ali $^{\mathrm{e}}$, Akram. A. Aboseidah ${ }^{\mathrm{a}}$ \\ ${ }^{a}$ Botany and Microbiology Department, Faculty of Science, Suez University, Suez, Egypt, \\ ${ }^{b}$ Agric. Botany Department, Faculty of Agriculture, Suez Canal University, Ismailia, 41522, Egypt, \\ ${ }^{c}$ Pharmacognosy Department, Faculty of Pharmacy, Suez Canal University, Ismailia, Egypt, \\ ${ }^{d}$ Horticulture Department, Faculty of Agriculture, Suez Canal University, Ismailia, 41522, Egypt, \\ ${ }^{e}$ Environmental Sciences Department, Suez University, Suez, Egypt.
}

Received on: 10. 02. 2019

Revised on: 19. 02. 2019

Accepted on: 23. 02. 2019

Correspondence Author:

Tel:+2 01140485181.

E-mail address:

abdelrazikeman1@gmail.com

\begin{abstract}
The effect of different concentrations of $\mathrm{NaCl}(6,8$ and $10 \mathrm{dS} / \mathrm{m})$ on growth and alkaloids production in 21 days-old callus of Egyptian henbane (Hyoscyamus muticus L.) was studied. Results showed that $10 \mathrm{dS} / \mathrm{m}$ of $\mathrm{NaCl}$ increased fresh and dry weight by 4.1 and 2.8 fold more than control, respectively. Total alkaloids increased by 2 fold at $10 \mathrm{dS} / \mathrm{m}$ compared to control or wild leaves. In contrary, wild leaves had the highest amount of hyoscyamine $(2.8 \mathrm{mg} / \mathrm{g} \mathrm{DW})$ followed by $6 \mathrm{dS} / \mathrm{m}$ stressed-callus $(1.14 \mathrm{mg} / \mathrm{g}$ DW) as detected by HPTLC. Peroxidase and superoxide dismutase activity were increased by 2.6 and 2.3 fold, respectively in highly salt stressed callus than control while catalase activity (CAT) was decreased. Anthocyanin concentration was increased 3 fold in $10 \mathrm{dS} / \mathrm{m}$ of $\mathrm{NaCl}$ stressed callus compared to control. Glutathione content was increased by $33.8 \%$ under low level of $\mathrm{NaCl}$ more than control. Reduction of photosynthetic pigments under all $\mathrm{NaCl}$ levels led to decrease the total carbohydrate and protein content. Protein band with molecular weight $109 \mathrm{KDa}$ was a unique band in $10 \mathrm{dS} / \mathrm{m}$ of $\mathrm{NaCl}$ treated callus with high expression of protein bands with MW 44, 38 and $32 \mathrm{KDa}$. Histologically, callus cells under high level of $\mathrm{NaCl}$ had amoeboid shape and start in senescence with formation of lysiogenous intercellular spaces. It can be concluded that, using of $\mathrm{NaCl}$ as elicitor was effective method for enhancing the growth and alkaloids
\end{abstract}

Keywords: Hyoscyamine, in vitro, protein electrophoresis, HPTLC, salt stress, biochemical compounds

\section{Introduction}

Salt stress is an important abiotic elicitor affecting plant growth, development, morphogenesis and the accumulation of secondary metabolites such as phenols, terpenes and alkaloids (Naik and Alkhayri, 2016; Selmar, 2008; Haghighi et al., 2012). $\mathrm{NaCl}$ stressor had stimulating or inhibiting effect on growth or synthesis of natural products according to its concentration, exposure period and plant species. In this respect, low concentration of $\mathrm{NaCl}$ (2000 ppm) enhanced the production of secondary metabolites in Mentha longifolia in vitro cultures but high concentration (6000 ppm) inhibited growth and yellowing cells (El-shennawy et al., 2017). Also, low $\mathrm{NaCl}$ level (1000 ppm) increased the total phenolics, total flavonoids and total tannins in callus culture of Fenugreek (Trigonella 
foenum-graecum ), while the higher concentration (3000 ppm) significantly decreased the secondary metabolite accumulation (Hussein and Aqlan, 2012). However, $25 \mathrm{mM}$ of $\mathrm{NaCl}$ stressed callus produced about three times of pilocarpine more than the unstressed callus (Abreu et al., 2005). Although root growth was decreased, secondary metabolite accumulation was increased with elevating level of $\mathrm{NaCl}$ compared control in madder plants ( Asci et al., 2018). Sitosterol content was increased in Nitraria tangutorum cell suspension at $250 \mathrm{mM}$ $\mathrm{NaCl}$ treatment (Ni et al., 2015). Low increment of canavanine content was recorded in Sutherlandia frutescens in vitro shoot culture after exposure to $100 \mathrm{mM} \mathrm{NaCl}$ (Colling et al., 2010). Using of $\mathrm{NaCl}$ as an elicitor improved the synthesis of both vinblastine and vincristine in Catharanthus roseus embryogenic tissue culture (Fatima et al., 2015).

Tropane alkaloids are plant derived organic compounds that contain a tropane ring in their chemical structure and they are among the oldest medicines known to man. Tropane alkaloids have been found in different plant families, Brassicaceae, Convolvulaceae, Erythroxylaceae, Euphorbiaceae, Olacaceae, Proteaceae, and Rhizophoraceae, but they are best known for their occurrence in the family Solanaceae (Griffin and Lin, 2000). Hyoscyamus muticus, commonly known as the Egyptian henbane, is a shrub belongs to family Solanaceae, is a rich source of tropane alkaloids which have mydriatic, anticholinergic and antispasmodic properties. Hyoscyamine represents $90 \%$ of the total alkaloids in addition to small amounts of hyoscine in Hyoscyamus muticus (Batanouny et al., 1999). The present study was carried out to investigate the effect of salt stress by different concentration of $\mathrm{NaCl}$ on callus growth, histological structure, biochemical parameters, and alkaloid production from Hyoscyamu muticus $\mathrm{L}$.

\section{Materials and methods}

\subsection{Seeds sterilization and germination:}

Wild Hyoscyamus muticus L. seeds were collected from Saint Catherine peninsula and identified according to Tackholm, (1974). To break a seed dormancy, it were immersed in $250 \mathrm{mg}^{-1}$ of gibberellic acid $\left(\mathrm{GA}_{3}\right)$ for $24 \mathrm{~h}$ at lab. temperature $\left(25 \pm 0.5^{\circ} \mathrm{C}\right)$ (Alaghemand et al., 2013). Then washed with tap water and surface-sterilized with $70 \%$ ethanol for $2 \mathrm{~min}$., then in $25 \%$ commercial bleach (containing $5.25 \%$ sodium hypochlorite) with a drops of tween-80 for 20 min and finally rinsed 3 times with double distilled sterilized water. The sterilized seeds were cultured in hormone-free MS medium (Murashige and Skoog), supplemented with $7 \mathrm{~g} \mathrm{l}^{-1}$ agar and $15 \mathrm{~g}^{-1}$ sucrose and maintained at $25 \pm 1{ }^{\circ} \mathrm{C}$ under light condition $(1,500$ lux, 16 $\mathrm{h} /$ day) for germination. After germination, plantlets have been obtained for explants preparation.

\subsection{Explant culture and callus induction:}

Shoot tip (18 days-old) were excised and cultured in MS media supplemented with different concentrations of BAP $\left(0.5 \mathrm{mg} \mathrm{l}^{-1}\right)$ and NAA $(0.5,1$ and $\left.2 \mathrm{mg}^{-1}\right), \mathrm{pH}(5.7-5.8)$ for callus induction with 10 replicate. The cultures were incubated at $\left(25 \pm 1 \mathrm{C}^{\circ}\right)$ with $(16 / 8)$ light/dark cycle. After 4 weeks more suitable callus were selected for further work.

\subsection{Elicitation treatments:}

After four weeks, callus were removed from vessels under aseptic condition and cut a suitable weight $(500 \mathrm{mg})$ and subculture on the same medium for further proliferation. $\mathrm{NaCl}$ added to the medium at different concentrations 6,8 and 10 $\mathrm{dS} / \mathrm{m}$ to initiate salt stress. Callus cultures were incubated at $25 \pm 1{ }^{\circ} \mathrm{C}$ under light condition $(1,500$ lux, $16 \mathrm{~h} /$ day). After 21 days treatment callus were harvested and washed with distilled water to remove remains agar and dried by filter paper.

\subsection{Vegetative measurements:}

Forty pieces of callus fresh weight (FW) and dry weight (DW) after drying at $70^{\circ} \mathrm{C}$ until constant weight was recorded. Water content (WC) of callus was calculated using FW and DW values according to Henson et al. (1981).

\subsection{Biochemical determinations:}

Photosynthetic pigments (mg $100 \mathrm{~g}^{-1} \mathrm{FW}$ ) in callus (chl. a, b and carotenoids) were extracted with $85 \%$ of acetone and estimated spectrophotometrically at 662, 644 and $440.5 \mathrm{~nm}$ (Arnon, 1949). Anthocyanins concentration (mg $\mathrm{g}^{-1} \mathrm{FW}$ ) was determined after digesting callus with $1 \%$ of $\mathrm{HCl}$ $(\mathrm{v} / \mathrm{v})$ in methanol and kept overnight at $4^{\circ} \mathrm{C}$ (Lange et al., 1971). Then centrifuged at $3000 \mathrm{rpm}$ for 10 $\min$ at $5^{\circ} \mathrm{C}$. The values are calculated as $\mathrm{E}_{535}-0.25$ $\left(\mathrm{E}_{650}\right) / \mathrm{g} \mathrm{FW}$. Total carbohydrates $\left(\mathrm{mg} \mathrm{g}^{-1} \mathrm{DW}\right)$ were determined according to Hedge and Hofreiter, (1962), dried samples digested by $5 \mathrm{ml}$ of $2.5 \mathrm{~N}$ $\mathrm{HCl}$ for 3 hours at $100^{\circ} \mathrm{C}$. Then naturalized with sodium carbonate. Sample was made volume up to $10 \mathrm{ml}$ and then filtrated. $50 \mu 1$ was diluted to $1 \mathrm{ml}$ with distilled water. To each tube, $1 \mathrm{ml}$ of $5 \%$ 
phenol and $5 \mathrm{ml}$ of $96 \% \mathrm{H} 2 \mathrm{SO} 4$ were added. After $10 \mathrm{~min}$, tubes were shaken at $25-30{ }^{\circ} \mathrm{C}$ for $20 \mathrm{~min}$. Optical density was measured at $490 \mathrm{~nm}$ as reported in. Total protein $(\mathrm{mg} / \mathrm{g} \mathrm{FW})$ was determined by Bradford method (Bradford, 1976) at $595 \mathrm{~nm}$. Proline as $\mathrm{mg} \mathrm{g}^{-1} \mathrm{FW}$ was estimated with ninhydrin reagent as described by Bates et al. (1973), the red color intensity was measured at $520 \mathrm{~nm}$ against the toluene blank. Total glutathione ( $\mu \mathrm{mol} / \mathrm{mg}$ protein) was determined at $412 \mathrm{~nm}$ by $5-5$ '-Dithiobis (2nitrobenzoic acid) (DTNB) reagent (Griffith, 1980). For determination of total free amino acids and free phenols alcohol extraction of callus was prepared as Abdel-Rahman et al. (1975).Free phenolics ( $\mathrm{mg} \mathrm{g}^{-1}$ FW) were determined by a modified FolinCiocalteu method and measured at $650 \mathrm{~nm}$ according to Horwitz et al., (1970). Total free amino acids ( $\mathrm{mg} \mathrm{g}^{-1} \mathrm{FW}$ ) was estimated using the method of Rosen colour (1957) with ninhydrin reagent .The blue colored was measured against blank sample at $570 \mathrm{~nm}$. Hydrogen peroxide $(\mathrm{mmol} / \mathrm{g} \mathrm{FW})$ was determined at $390 \mathrm{~nm}$ by the modified method according to Shi et al., (2007) from Sun et al., (2007). Malondialdehyde ( $\mu$ mol.g ${ }^{-1}$ FW) determined by the thiobarbituric acid (TBA) reaction as described by Gallego et al., (1996) from Heath and Packer, (1968). All spectrophotometric analyses were done using UV/VIS spectrophotometer, PG instrument Ltd, USA.

\subsection{Enzymatic antioxidants activity:}

Enzymes solutions were prepared according to Urbanke et al., (1991). Catalase (CAT, E.C.:1.11.1.6) activity was determined by measured the oxidation of $\mathrm{H}_{2} \mathrm{O}_{2}$ at $240 \mathrm{~nm}$ (Urbanek et al., 1991). The unit of CAT activity was defined as the amount of enzyme, which decomposes $1 \mathrm{mM} \mathrm{H}_{2} \mathrm{O}_{2}$ per $\mathrm{mg}^{-1}$ protein.minute. Peroxidase (POD, E.C.: 1.11.1.7) activity estimated with $0.1 \%$ O-dianisidine and $0.2 \mathrm{M}$ hydrogen peroxide at $430 \mathrm{~nm}$ (Urbanek et al., 1991). One unit of peroxidase activity was taken as the change of 1.0 unit of optical density per $\mathrm{mg}^{-1}$ protein.minute. Superoxide dismutase (SOD, E.C.: 1.15.1.1 ) activity was assayed by measuring its ability to inhibit reduction of nitro blue tetrazolium at $560 \mathrm{~nm}$ as described with (Beauchamp and Fridovich, 1971). One unit of enzyme activity represents the amount of enzyme required for $50 \%$ inhibition of NBT reduction.

\subsection{SDS-PAGE of soluble proteins}

One dimensional SDS-PAGE gel electrophoresis based on the method of Laemmli, (1970) was used to fractionate the soluble proteins in callus. Twenty milligrams of callus were dispersed in $1 \mathrm{ml}$ SDS $10 \%$ with $100 \mu \mathrm{l} \beta$-mercaptoethanol for $15 \mathrm{~min}$, then centrifuged at $11000 \mathrm{rpm}$ for $10 \mathrm{~min}$. Twenty $\mu \mathrm{l}$ of extraction were mixed with $20 \mu \mathrm{l}$ of SDSloading sample buffer (SDS 4\%, $\beta$-mercaptoethanol $3 \%$, glycerol $20 \%$, Tris $\mathrm{HCl} 50 \mathrm{mM} \mathrm{pH} 6.8$ and bromophenol blue traces), heated at $96{ }^{\circ} \mathrm{C}$ for $3 \mathrm{~min}$ and $10 \mu \mathrm{l}$ aliquot was electrophoresed $(10 \mu \mathrm{l}$ of protein/ lane). The resolving and stacking gels were prepared according to the standard procedure of Davis, (1964). The electrode buffer contained 50 $\mathrm{mM}$ TRIS, glycine $0.384 \mathrm{M}$ and SDS $0.1 \%$. The protein bands were developed with Commassie Brilliant Blue R-250 dye (0.2\% solution, freshly prepared in $45 \%$ methanol, $10 \%$ glacial acetic acid and $45 \%$ distilled water) at room temperature overnight. The gel was photographed and made by scan apparatus as densitometric (optical density) analysis at $600 \mathrm{~nm}$ using standard maker protein (Pharmacia).

\subsection{Histological investigations}

For longitudinal sections ( $15 \mu \mathrm{m}$ thick), callus was fixed in formalin acetic acid (FAA), then dehydrated with ethanol series and cleared with ethanol-xylene. Then samples were embedded in paraffin wax at $45-55^{\circ} \mathrm{C}$ (Johansen, 1940). Sections were cut with steel blade on rotary microtome. The fixed sections were stained with Safranin O-Fastgreen double stain. After staining, sections mounted in Canada balsam (Sass, 1961). Observation and photomicrographs were achieved using research microscope (LEICA DM500) fitted with digital camera (LEICA ICC50). For staining alkaloid, callus was macerated and stained with Dragendorff's reagent.

\subsection{Alkaloids determination}

For alkaloids extraction, powdered dry callus was percolated overnight in methanol till complete exhaustion, and then methanol was removed by distillation under For alkaloids extraction. The residue obtained was stirred with $0.1 \mathrm{~N} \mathrm{HCl}$ and extracted with $\mathrm{CH}_{3} \mathrm{Cl}$. The chloroform layer was washed with $0.1 \mathrm{~N} \mathrm{HCl}$ and discarded. The combined acidic layer was then rendered alkaline with $\mathrm{NH}_{4} \mathrm{OH}$ and extracted with $\mathrm{CH}_{3} \mathrm{Cl}$. The organic layer was collected then dried under vacuum to afford the crude alkaloid extract

(Karawya et al., 1975). Total alkaloids concentration was determined using the method 
reported in Ajanal et al., 2012; which in brief depends on the reaction between Bromocresol green and alkaloids in $\mathrm{pH} 4.7$ to form a yellow colored complex which is extractable in chloroform and the color intensity obey Beer Lambert's law.

Atropine standard solution was made by dissolving $1 \mathrm{mg}$ of Atropine (Sigma) in $10 \mathrm{ml}$ distilled water. The absorbance of the complex in chloroform was measured at spectrum of $470 \mathrm{~nm}$ in UV/VIS spectrophotometer, PG instrument Ltd, USA against the blank prepared as above but without atropine.

Table 1: Description of Hyoscyamus muticus L. callus after 21 days as affected by different concentrations of $\mathrm{NaCl}$.

\begin{tabular}{|c|c|c|c|c|c|}
\hline $\begin{array}{c}\mathrm{NaCl} \\
(\mathrm{dS} / \mathrm{m})\end{array}$ & \multicolumn{3}{|c|}{ Cell } & $\begin{array}{c}\text { Symmetric } \\
\text { of cells }\end{array}$ & $\begin{array}{c}\text { Intercellular } \\
\text { space }\end{array}$ \\
\cline { 2 - 5 } & Shape & $\begin{array}{c}\text { length } \\
\mu \mathrm{m}\end{array}$ & $\begin{array}{c}\text { width } \\
\mu \mathrm{m}\end{array}$ & & \\
\hline $\begin{array}{c}0.0 \\
(\text { control) }\end{array}$ & $\begin{array}{c}\text { regular } \\
\text { ovate }\end{array}$ & $72 \mathrm{~b}$ & $54 \mathrm{c}$ & Symmetric & schizogenous \\
\hline 6 & $\begin{array}{c}\text { irregular } \\
\text { amoeboid }\end{array}$ & $108 \mathrm{a}$ & $81 \mathrm{a}$ & Symmetric & schizogenous \\
\hline 8 & spherical & $109 \mathrm{a}$ & $73 \mathrm{~b}$ & symmetric & schizogenous \\
\hline 10 & $\begin{array}{c}\text { tregular } \\
\text { amoeboid }\end{array}$ & $73 \mathrm{~b}$ & $51 \mathrm{c}$ & symmetric & Lysiogenous \\
\hline
\end{tabular}

\subsection{Determination of Hyoscyamine concentration:}

High-Performance Thin-Layer Chromatography (HPTLC) was performed on $20 \mathrm{~cm} \times 10 \mathrm{~cm}$ HPTLC silica gel $60 \mathrm{~F}_{254}$ plates (Merck) with a mobile phase consisting of chloroform : methanol : acetone : aqueous ammonia (25\%) $75: 15: 10: 1.6(\mathrm{v} / \mathrm{v} / \mathrm{v} / \mathrm{v})$ (Jaremicz et al., 2014). Hyoscyamine standard (Sigma) was diluted by chloroform to final concentration 20,40,60,80,120,160 $\mu \mathrm{g} / \mathrm{ml}$. All samples and standards were applied to the plates by means of CAMAG Linomat 5 with dosing syringe $100 \mu \mathrm{L}$ as $7 \mathrm{~mm}$ bands with $10.5 \mathrm{~mm}$ distance between tracks, application X $15 \mathrm{~mm}$ and $13 \mathrm{~mm}$ application $\mathrm{Y}$ edges of plate and the application volume was $1-20 \mu \mathrm{L}$ for samples and $2-8 \mu \mathrm{L}$ for standard. Loaded HPTLC plates were developed to a distance of $50 \mathrm{~mm}$ in Camag Automatic Developing Chamber CADC 2 at room temperature. The development occurring in a two- steps
(Preconditioning with $10 \mathrm{ml}$ mobile phase for 5 minutes and development with $25 \mathrm{ml}$ mobile phase for 20 minutes). The plate was developed to a distance of $50 \mathrm{~mm}$ and dried for $5 \mathrm{~min}$ by a stream of warm air, then the plates derivatized with $200 \mathrm{ml}$ Dragendorff's reagent using Chromatogram Immersion Device. Then the plate was scanned and examined densitometry at $1=550 \mathrm{~nm}$ by means of CAMAG TLC Scanner 4 with slit dimension of $6 x$ $0.30 \mathrm{~mm}$.

\subsection{Statistical analysis}

All data were statistically analyzed as randomized complete blocks design (Steel et al., 1997). Analysis of variance (one-way analysis; ANOVA) and means comparisons (Duncan's multiple range tests, 5\%) were performed using the MSTAT-C statistical pack-age (M-STAT, 1990).

A
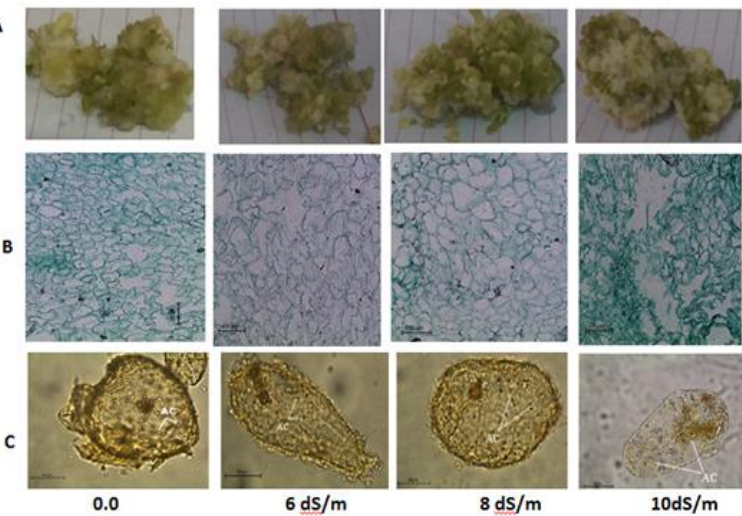

Figure 1: Effect of different concentrations of $\mathrm{NaCl}$ on growth (A), histology (B) and orangestained alkaloid crystals (C) in callus of Hyoscyamus muticus L., after 21 days

\section{Results and discussion:}

\subsection{Results}

3.1.1. Growth, histological description and alkaloid crystals of callus cells:

The stimulating effect of different levels of $\mathrm{NaCl}$ on callus growth after 21days showed in Figure (1). Shape of callus cells differed according to $\mathrm{NaCl}$ levels as shown in Figure (1B). Cells had ovate or spherical shape in $8 \mathrm{dS} / \mathrm{m}$ of $\mathrm{NaCl}$ and unstressed callus while it was amoeboid in low or high levels of salt stressed one. The highest values of cell length and width were found in 6 and $8 \mathrm{dS} / \mathrm{m}$ of $\mathrm{NaCl}$ stressed callus compared to control or High level of $\mathrm{NaCl}$ stressed one. Lysiogenous 
intercellular space was abundant in high level of $\mathrm{NaCl}$ exposed callus compared to schizogenous one in other treatments. Higher abundance of orangestained crystals of alkaloids in callus cells was found in all salt stressed callus cells especially under $10 \mathrm{dS} / \mathrm{m}$ of $\mathrm{NaCl}$ as shown in Figure (1C).

\subsubsection{The vegetative growth and total carbohydrates of callus:}

The fresh (FW) and dry (DW) weight of henbane callus were gradually increased with increment of $\mathrm{NaCl}$ level in MS medium. High level of $\mathrm{NaCl}(10$ $\mathrm{dS} / \mathrm{m}$ ) increased the FW and DW by 4.1 and 2.8 fold more than control, respectively (Figure 2A,B). Slight increment $(1 \%)$ of water content in salt stressed callus compared to unstressed callus was observed (Figure 2C). Total carbohydrate content significantly reduced under all $\mathrm{NaCl}$ levels. The highest reduction of total carbohydrates (24.3\%) was determined in $10 \mathrm{dS} / \mathrm{m}$ of $\mathrm{NaCl}$ stressed callus compared to control as showed in (Figure 2D).

\subsection{3. pigments:}

Photosynthetic pigments (Chl. a, b, and carotenoid) concentrations were gradually decreased in callus under all $\mathrm{NaCl}$ levels compared to untreated one. The highest reduction of Chl.a and carotenoid concentration by 31.5 and $26 \%$ was observed at high $\mathrm{NaCl}$ level $(10 \mathrm{dS} / \mathrm{m})$ lower than control, respectively (Figure 3A,C). Also, the highest reduction of Chl. b (28.1\%) was observed in callus treated with moderate level of $\mathrm{NaCl}(8 \mathrm{dS} / \mathrm{m})$ compared to control (Figure 3B). In contrary, anthocyanin content was increased 3 fold in 10 $\mathrm{dS} / \mathrm{m}$ of $\mathrm{NaCl}$ stressed callus compared to untreated one as shown in Figure (3D).

\subsubsection{Nonenzymatic antioxidants and $\mathrm{H}_{2} \mathrm{O}_{2}$}

Both free phenolics and glutathione concentrations had opposite trend in response to $\mathrm{NaCl}$ treatments. So free phenolics were decreased by 21 and $30 \%$ (Figure 4B) the glutathione content was increased by 34 and $20 \%$ (Figure 4A) in 6 and $8 \mathrm{dS} / \mathrm{m}$ of $\mathrm{NaCl}$ stressed callus respectively compared to control. Also, the content of both phenolics and glutathione increased by 8 and $4.6 \%$ in $10 \mathrm{dS} / \mathrm{m}$ of $\mathrm{NaCl}$ streesed callus more than control, respectively but without significant differences. Data in Figure (4C) indicated the slight reduction in proline content at 6 and $8 \mathrm{dS} / \mathrm{m}$ of $\mathrm{NaCl}$ stressed callus, but marked reduction occurred at $10 \mathrm{dS} / \mathrm{m}$ by $50.6 \%$ in relation to control. The lowest value
( $1.53 \mathrm{mmol} / \mathrm{g} \mathrm{FW}$ ) of $\mathrm{H}_{2} \mathrm{O}_{2}$ was determined in 10 $\mathrm{dS} / \mathrm{m}$ of $\mathrm{NaCl}$ stressed callus with reduction by $16.8 \%$ compared to untreated one (Figure 4D).
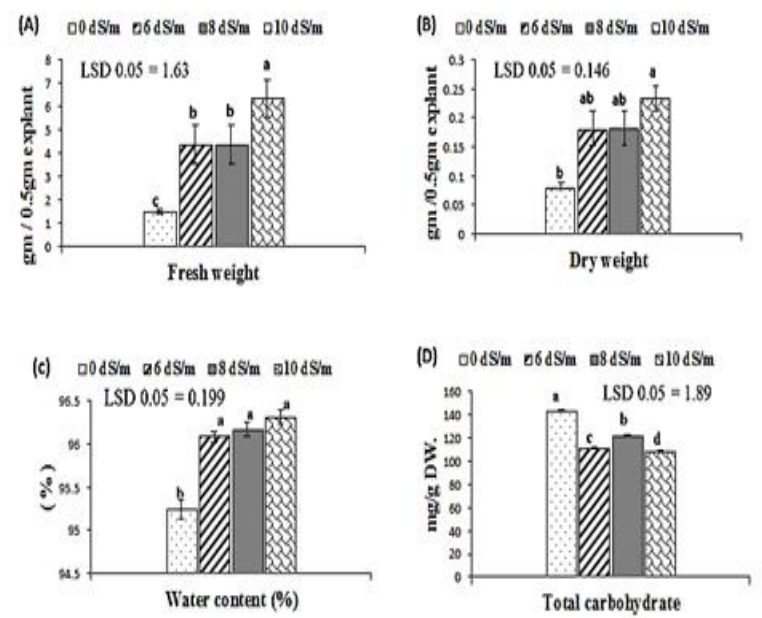

Figure 2: Effect of different concentrations of $\mathrm{NaCl}$ on fresh, dry weight, water content and total carbohydrate of callus of Hyoscyamus muticus L., after 21 days.
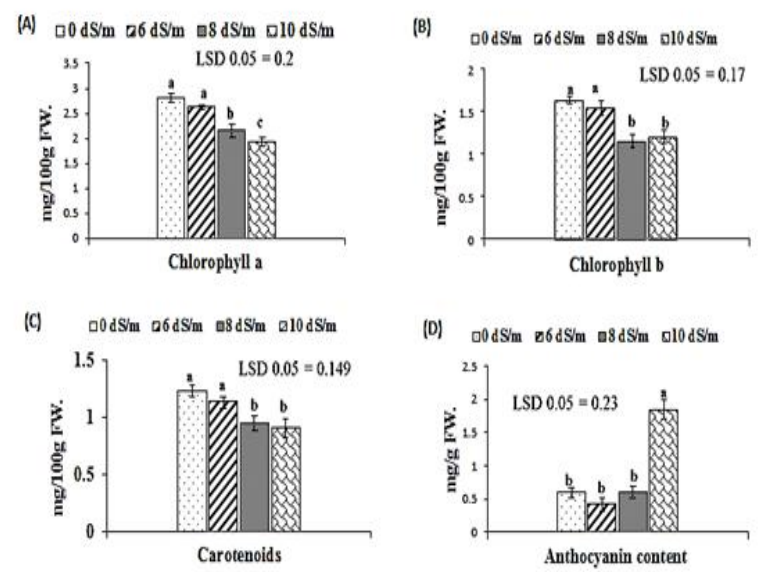

Figure 3: Effect of different concentrations of $\mathrm{NaCl}$ on pigments (Chl a, Chl b, carotenoid and anthocyanin) of callus of Hyoscyamus muticus L., after 21 days.

\subsubsection{Enzymatic antioxidants and MDA}

The activity of peroxidase (POD) and superoxide dismutase (SOD) were increased with rising of $\mathrm{NaCl}$ level in MS medium, while the catalase (CAT) activity was decreased as shown in Figure (5) . Activity of POD and SOD increased by 2.6 and 2.3 fold in $10 \mathrm{dS} / \mathrm{m}$ of $\mathrm{NaCl}$ stressed callus more than untreated callus, respectively. However, malondialdehyde (MDA) content was decreased 
under salt stress condition compared to normal one. The minimum concentration $(1.27 \mu \mathrm{mol} / \mathrm{g} \mathrm{FW})$ of MDA was found in $8 \mathrm{dS} / \mathrm{m}$ of $\mathrm{NaCl}$ stressed with $56.7 \%$ reduction lower than control (Figure 5D).
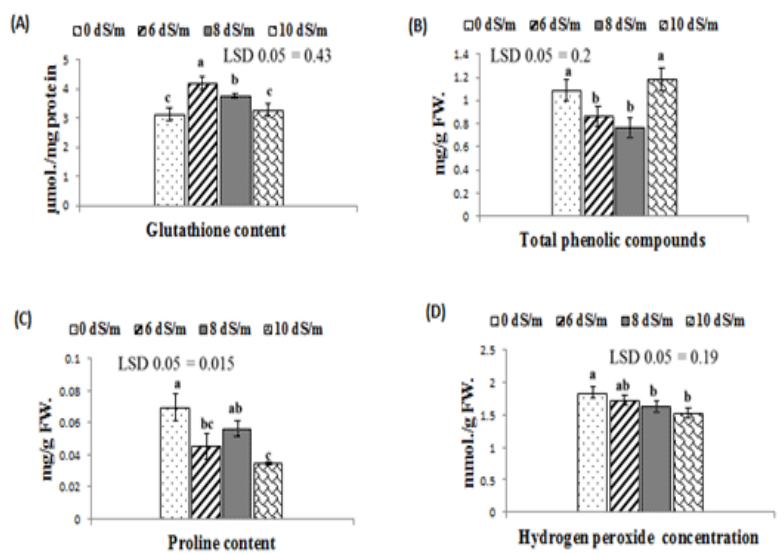

Figure 4: Effect of different concentrations of $\mathrm{NaCl}$ on glutathione (A), total phenolic compound (B), proline (C), and $\mathrm{H}_{2} \mathrm{O}_{2}$ (D) of callus of Hyoscyamus muticus L., after 21 days.

\subsubsection{Alkaloids and nitrogenous compounds}

Protein content was gradually decreased by 41.2 , 17.1 and $11.7 \%$ in, 6,8 and $10 \mathrm{dS} / \mathrm{m}$ of $\mathrm{NaCl}$ stressed callus respectively, compared to control (Figure 6B). The concentration of free amino acids was decreased in callus under both low and moderate level by 48 and $18.4 \%$ compared to control, respectively. Increment of free amino acids content was observed in $10 \mathrm{dS} / \mathrm{m}$ of $\mathrm{NaCl}$ stressed callus without significant differences with control (Figure 6A). Total alkaloids content was increased 2 -fold in callus treated with $10 \mathrm{dS} / \mathrm{m}$ of $\mathrm{NaCl}$ compared to untreated callus or wild leaves. Moreover, low and moderate level of $\mathrm{NaCl}$ reduced the total alkaloid by 22.7 and $11.5 \%$, respectively compared to control or wild plants (Figure 6C). In contrary, hyoscyamine content was decreased under all $\mathrm{NaCl}$ levels. In this respect, wild leaves synthesized the highest amount $(2.8 \mathrm{mg} / \mathrm{g} \mathrm{DW})$ of hyoscyamine which was double amount as low $\mathrm{NaCl}$ level (Figure 7).

\subsection{7.protein profile}

Soluble protein of $\mathrm{NaCl}$ stressed or unstressed callus were electrophoretic analyzed by one dimensional SDS-PAGE gel as showed in Figure (8). Densitometric analysis revealed that soluble protein was fractioned into 7 varied bands with molecular weights (MW) 240, 109 , 44, 38, 32, 16 and 10 $\mathrm{KDa}$. The unique band (109 KDa) was only expressed in $10 \mathrm{dS} / \mathrm{m}$ stressed callus. Bands with MW 240, 16 and 10 had high expression (as high optical density) in $8 \mathrm{dS} / \mathrm{m}$ of $\mathrm{NaCl}$ stressed callus. While, bands with MW 44, 38 and 32 had high expression in $10 \mathrm{dS} / \mathrm{m}$ of $\mathrm{NaCl}$ stressed callus. Protein bands were similar by $100 \%$ between unstressed callus and 6 or $8 \mathrm{dS} / \mathrm{m}$ of $\mathrm{NaCl}$ stressed one, then similarity \% was low with $10 \mathrm{dS} / \mathrm{m}$ of $\mathrm{NaCl}$ stressed one.

(A)
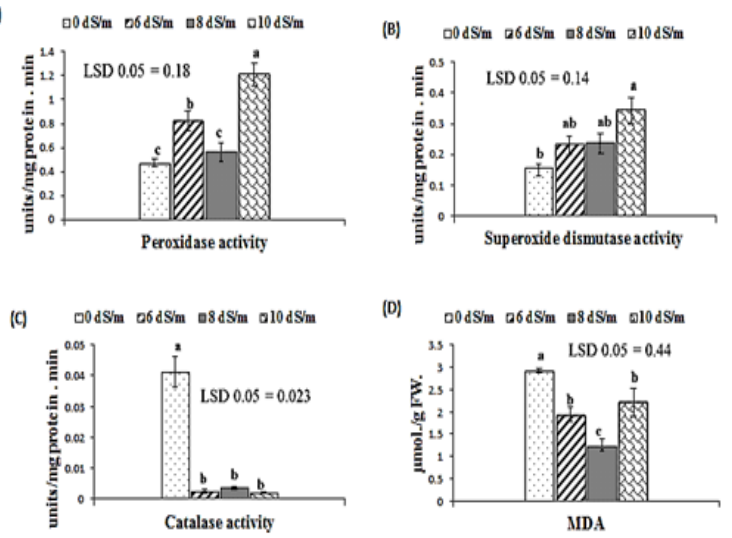

Figure 5: Effect of different concentrations of $\mathrm{NaCl}$ on POD (A), SOD (B), CAT (C), and MDA (D) of callus of Hyoscyamus muticus L., after 21 days.
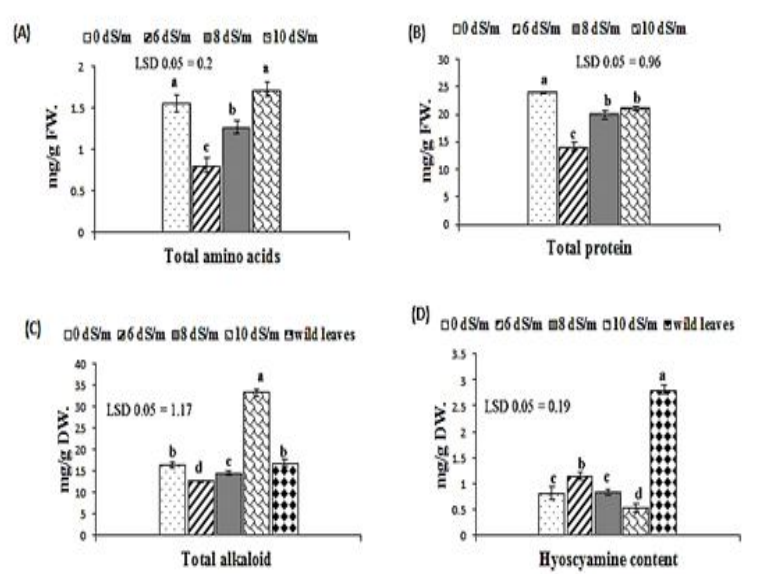

Figure 6: Effect of different concentrations of $\mathrm{NaCl}$ on free amino acids (A), protein (B), total alkaloid (C), and hyoscyamine (D) of callus of Hyoscyamus muticus L., after 21 days.

\subsection{Disscusion:}

Creating a case of salt stress in the medium of plant callus cultures is a potential method for 
secondary metabolites accumulation which may be much more effective than studies performed on intact plant due to the absence of root barrier (Vanishree et al., 2004; Namdeo, 2007). Results reported herein showed that the total alkaloids concentration had doubled under high level of $\mathrm{NaCl}(8 \mathrm{dS} / \mathrm{m})$ compared to unstressed callus or wild leaves, while the hyoscyamine accumulation was higher in wild leaves compared to all $\mathrm{NaCl}$ stressed callus (Figure 7). However, the concentration of hyoscyamine was increased by 40 $\%$ in callus treated with low level of $\mathrm{NaCl}(6 \mathrm{dS} / \mathrm{m})$ compared to untreated one. Results were agreed with Mahajan et al., (2005) who reported that high salt stress may be increase or decrease a specific secondary metabolite in plants.

The data obtained from our investigation revealed that callus cells of Egyptian henbane were tolerant to $\mathrm{NaCl}$ salt stress due to the enhancement of both fresh and dry biomass as shown in (Figure 2). These findings were found in different plant species such as in vitro Cassava plantlets treated with $10 \mathrm{mM} \mathrm{NaCl}$ (Cheng et al., 2018). In contrary, Aljibouri et al., (2012) found a reduction of both FW and DW of Hyoscyamus niger callus after application of abiotic elicitors. Results cleared that Photosynthetic pigments such a Chl a, b and carotenoids were susceptible to salt stress due

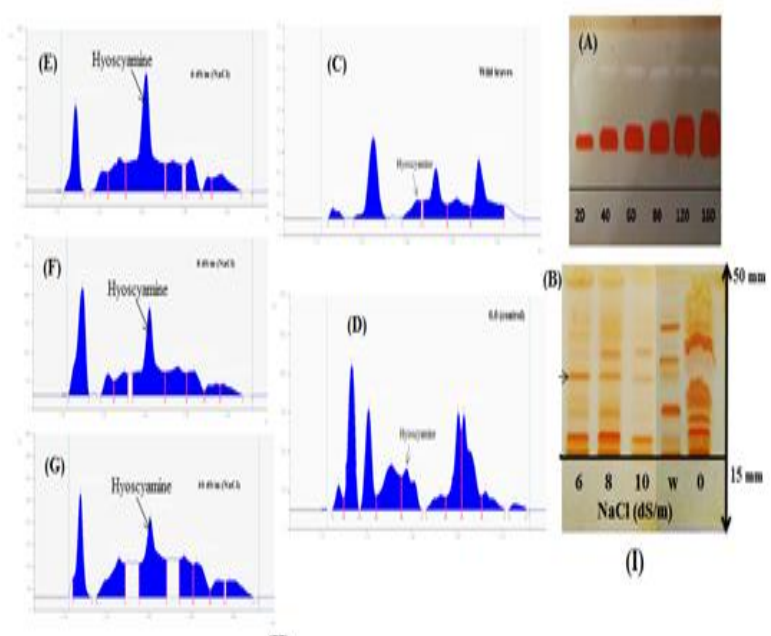

(II)

Figure 7: (I) Chromatogram of alkaloid fraction from (A) hyoscyamine standard solutions $(\mu \mathrm{g} / \mathrm{ml})$ and (B) Hyoscyamus muticus callus. (II) Densitogram of alkaloid fraction from Hyoscyamus muticus callus recorded at $\lambda=550 \mathrm{~nm}$ after derivatisation with Dragendorff's reagent, $(C)$ wild leaves, (D) untreated callus, (E) $6 \mathrm{dS} / \mathrm{m} \mathrm{NaCl}$, (F) 8 $\mathrm{dS} / \mathrm{m} \mathrm{NaCl}$ and $(\mathrm{G}) 10 \mathrm{dS} / \mathrm{m} \mathrm{NaCl}$. to its reduction under all $\mathrm{NaCl}$ levels, while anthocyanin was a stable pigments, so it increased by 3.1 fold compared to unstressed callus (Figure 3). Decreasing the Chls. content in the salt-affected plants could be due to the destruction of the alkaloid protein complex or degradation of Chls. by chlorophyllase (Rao and Rao, 1981). Under salt stress the photosynthetic pigments were decreased in callus of different species such as of Capsicum annuum (Sen and Alikamanoglu, 2011) and wheat (El-Kaaby et al., 2017).

Our results reinforced the hypothesis that anthocyanin participated in salt resistance mechanism in tolerant plant species as tomato and red cabbage (Steyn et al., 2002 and WinkelShirley, 2002, Eryılmaz, 2006).

High salt concentrations resulted in oxidative stress due to the formation of reactive oxygen species. Effective enzymatic and nonenzymatic antioxidant system is one of the most common protection mechanism that plants evolve to stabilize important macromolecules which deleteriously affected by the ROS. (Shi et al. 2006). Results cleared that henbane callus depend on peroxidase (POD) and superoxide dismutase (SOD) more than catalase (CAT) as enzymatic antioxidant mechanism to quench the ROS under salt stress, as POD and SOD were significantly increased by 2.6 and 2.3 fold in $10 \mathrm{dS} / \mathrm{m}$ of $\mathrm{NaCl}$ stressed callus compared to control, respectively, while CAT activity was decreased (Figure 5). This findings were agreed with Foyer and Noctor (2000) who reported that, SOD is a key enzyme that plays an important role in cellular defense and catalyze the dismutation of superoxide radicals to $\mathrm{H}_{2} \mathrm{O}_{2}$ and superoxide. Also, Yamasaki et al., (1997) reported that POD is oxidoreductase, which efficiently catalyze the oxidation of $\mathrm{H}_{2} \mathrm{O}_{2}$ with phenolic compounds or ascorbic acid. Enhancement of POD and SOD activity was detected in different plant species under salt stress as Jatropha curcas callus( Kumar et al., 2008) and Punica granatum callus (Bonyanpour and Khosh-Khui, 2013) Capsicum annuum callus (El-Kaaby et al., (2017) callus cultures of sugarcane (Munir and Aftab, 2013). Reduction of CAT activity also reported in callus of different species such as Solanum tuberosum (Queirós et al., 2011) and Salsola baryosma (Sharma and Ramawat, 2014). Results also showed that, glutathione content was significantly increased by 34 and $20 \%$ at 6 and $8 \mathrm{dS} / \mathrm{m}$, 
respectively compared to control. This finding was in line with Queirós et al., (2011) who found the reduction of glutathione reductase activity in saltexposed callus of Solanum tuberosum. Free amino acids were slightly increased by $10.7 \%$ in $10 \mathrm{dS} / \mathrm{m}$ of $\mathrm{NaCl}$ stressed callus compared to control (Figure 6A). Results were coordinated with Hartzendorf and Rolletschek, 2001 who found a significantly increment of total free amino acids after application of $\mathrm{NaCl}$ in Phragmites australis. However, both free phenolics and proline content were decreased in callus under all $\mathrm{NaCl}$ levels (Figure 4). This result was in opposite with Ahmed et al., (2012). who found increment of total phenolic in Garden cress cultured under $\mathrm{NaCl}$ treatment, in Trianthema triquetra callus cultures (Sharma and Ramawat, 2014). Also, proline increased in callus culture of Salsola baryosma, Trianthema triquetra and Zygophyllum simplex under the salinity stress (Sharma and Ramawat, (2014).

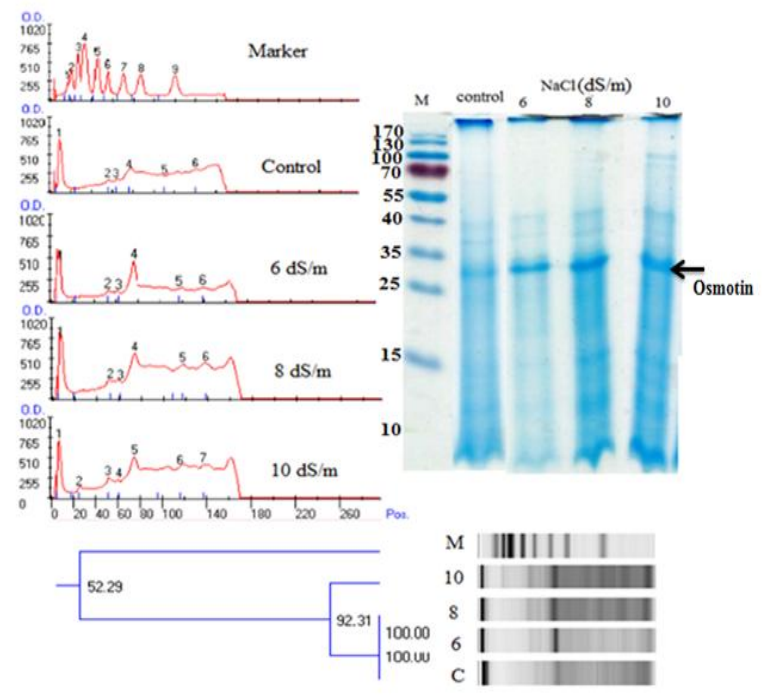

Figure 8: SDS-PAGE of protein profile, optical densities of each protein band and similarity of each concentration of $\mathrm{NaCl}$ of callus of Hyoscyamus muticus L., after 21 days.

Decreasing of Malondialdehyde (MDA) and $\mathrm{H}_{2} \mathrm{O}_{2}$ concentration to minimum values $(1.265 \mu \mathrm{mol}$. $/ \mathrm{gFW}$ and $1.53 \mathrm{mmol} / \mathrm{gFW}$, respectively) in henbane callus under all $\mathrm{NaCl}$ levels may be attributed with effective function of anthocyanin, glutathione, POD and SOD activity in scavenging the ROS under salt stress. This result was in line with Queirós et al., (2011) who found that lipids peroxidation were found in salt sensitive callus in Solanum tuberosum. The $\mathrm{H}_{2} \mathrm{O}_{2}$ concentration was increased in four cassava cultivars in vitro shoots and decreased in another one under salt stress (Cheng et al., 2018).

Protein (Figure 6B) and carbohydrate content (Figure 2D) were reduced in all $\mathrm{NaCl}$ levels. This reduction may be due to its degradation by active ROS (El-Mashad and Mohamed, 2012). Protein degradation may be essential to provide amino acids for synthesis of new proteins as osmotin suited for growth or survival under stress conditions and also substrates for energy production (Kocisko et al., 1994). Reduction of protein content was occurred in different plants under salt stress as wheat (Sen and Alikamanoglu, 2011), Salsola baryosma, Trianthema triquetra and Zygophyllum simplex (Sharma and Ramawat, 2014). In contrary, soluble sugars content increased in Atriplex halimus $\mathrm{NaCl}$ stresses (Martinez et al., 2004). Results reported herein showed that osmotin protein with molecular weight $32 \mathrm{KDa}$ was highly expressed in $10 \mathrm{dS} / \mathrm{m}$ of $\mathrm{NaCl}$ stressed callus. Results were in line with Hassanein, (1999) who reported that proteins with MW 127 and $52 \mathrm{kDa}$ highly induced in peanut under $\mathrm{NaCl}$ stress. Also, Kumar et al., (2008) found that protein bands with MW 98, 69, 66 and $64 \mathrm{kDa}$ were highly expressed in $\mathrm{NaCl}$ treated callus of Jatropha curcas while other bands with MW as 83,58 and $43 \mathrm{kDa}$ proteins were low expressed.

\section{Conclusion:}

$\mathrm{NaCl}$ at $10 \mathrm{dS} / \mathrm{m}$ gave the highest content of total alkaloids in Egyptian henbane callus culture. Hyoscyamine concentration was high in wild leaves than salt stressed callus. High accumulation of alkaloids and antioxidant agents under saline condition improved callus growth. Protein bands can be used as stable indicator for callus tolerance to salt stress.

\section{References}

Abdel-Rahman, M., Thomas, T. H., Doss, G. J., Howell, L. 1975: Changes in endogenous plant hormones in cherry tomato fruits during development and maturation. Physiologia plantarum, 34(1), 39-43.

Abreu, I. N. Sawaya, A.C.H. F., Eberlin, M. N., Mazzafera, P. 2005. Production of pilocarpine in callus of jaborandi (pilocarpus microphyllus stapf)', In Vitro Cellular and Developmental Biology - Plant, 41(6), pp. 806-811.

Ahmed, A. R., Gabr, A. M. M., Sayed, M. A. 2012. 
Effect of Drought and Salinity Stress on Total Phenolic, Flavonoids and Flavonols Contents and Antioxidant Activity in in vitro Sprout cultures of Garden cress (Lepidium sativum). Journal of Applied Sciences Research, 8(8), pp. 3934-3942.

Ajanal, M., Gundkalle, M. B. , Nayak, S. U. 2012. Estimation of total alkaloid in Chitrakadivati by UV-Spectrophotometer. Ancient science of life, 31(4), pp. 198-201.

Alaghemand, A., Ghorbanpour, M. , Moghaddasian, B. 2013. The Role of Gibberellic Acid, Sulfuric Acid and Cold Stratification. Bulletin of Environment, Pharmacology and Life Sciences, 2, 99-103.

Aljibouri, A. M. J., Al-samarraei, K. W., Abd, A. S., Mageed, D. M., Ali, A. J. A. 2012. Alkaloids Production from Callus of Hyoscyamus niger L . in Vitro. Journal of Life Sciences, 6, 874-882.

Arnon, D. I. 1949. Copper enzymes in isolated chloroplasts: polyphenol oxidase in Beta vulgaris. Plant physiology, 24(1), 1.

Aşci, Ö. A., Demirci, T., Baydar, N. G. 2018. Effects of $\mathrm{NaCl}$ applications on root growth and secondary metabolite production in madder (Rubia tinctorum L.) root cultures. International journal of secondary metabolite, 5(3), 210-216.

Batanouny, K. H., Aboutabl, E., Shabana, M., Soliman, F. 1999. Wild medicinal plants in Egypt. With support of the Swiss Development Cooperation (SDC). Academy of Scientific Research and Technology, Egypt. The World Conservation Union (IUCN), Switzerland, 60-64.

Bates, L. S., Waldren, R. P., Teare, I. D. 1973. Rapid determination of free proline for water-stress studies. Plant and soil, 39(1), 205-207.

Beauchamp C., Fridovich I. 1971. Superoxide dismutase: Improved assays and an assay applicable to acrylamide gels. Analytical biochemistry, 44:276287.

Breusegem, F. V., Dat, J. F. 2006. Reactive Oxygen Species in Plant Cell Death. Plant Physiology. 141 (2): 384-390.

Bonyanpour, A. , Khosh-Khui, M. 2013. Effects of salt and drought stress conditions on callus growth, proline content and antioxidant enzyme avtivity of
Punica granatum (Nana). BioTechnology: An Indian Journal, 7(7), pp. 257-262.

Bradford, M. M. 1976. A rapid and sensitive method for the quantitation of microgram quantities of protein utilizing the principle of protein-dye binding. Analytical biochemistry, 72(1-2), 248-254.

Chalker-Scott, L. 1999. Environmental significance of anthocyanins in plant stress responses. Photochemistry and photobiology, 70(1), 1-9.

Cheng, Y. E., Dong, M. Y., Fan, X. W., Nong, L. L., Li, Y. Z. 2018. A study on cassava tolerance to and growth responses under salt stress. Environmental and Experimental Botany, 155, 429-440.

Colling, J., Stander, M. A. Makunga, N. P. 2010. Nitrogen supply and abiotic stress influence canavanine synthesis and the productivity of in vitro regenerated Sutherlandia frutescens micro shoots. Journal of plant physiology, 167(17), pp. $1521-1524$.

Davis, B. J. 1964. Disc electrophoresis-II method and application to human serum proteins. Annals of the New York academy of sciences, 121(2), 404427.

El -Kaaby, E. ., AI-Anny, J. , Almaliky, E. S. 2017. In Vitro effect of exogenous $\mathrm{NaCl}$ on enzyme activity, chlorophyll and carotene accumulation in callus of chilli pepper (Capsicum annuum L .) explants. international journal of multidisciplinary and current research, 5, pp. 253-255.

El-Mashad, A. A. A. and Mohamed, H. I. 2012. Brassinolide alleviates salt stress and increases antioxidant activity of cowpea plants (Vigna sinensis). Protoplasma, 249(3), 625-635.

El-shennawy, O. A., El-torky, M. G., El-mokadem, H. E., Abass, B. I. 2017. Effect of $\mathrm{NaCl}$ and Phenylalanine on the Production of some Secondary Metabolites in In Vitro Cultures of Mentha longifolia. Alexandria science exchange journal, 38(3), 577-587.

Eryllmaz, F. 2006. The relationships between salt stress and anthocyanin content in higher plants. Biotechnology and biotechnological equipment, 20(1), 47-52.

Fatima, S., Mujib, A., Tonk, D. 2015. NaCl amendment improves vinblastine and vincristine 
synthesis in Catharanthus roseus: a case of stress signalling as evidenced by antioxidant enzymes activities. Plant Cell, Tissue and Organ Culture, 121(2), pp. 445-458.

Foyer, C. H., Noctor, G. 2000. Tansley Review No. 112 Oxygen processing in photosynthesis: regulation and signalling. The New Phytologist, 146(3), 359-388.

Gallego, S. M., Benavides, M. P., Tomaro, M. L. 1996. Effect of heavy metal ion excess on sunflower leaves: evidence for involvement of oxidative stress. Plant Science, 121(2), 151-159.

Griffin, W. J., Lin, G. D. 2000. Chemotaxonomy and geographical distribution of tropane alkaloids. Phytochemistry, 53(6), 623-637.

Griffith, O. W. 1980. Determination of glutathione and glutathione disulfide using glutathione reductase and 2-vinylpyridine. Analytical Biochemistry, 106(1), 207-212.

Haghighi, Z., Modarresi, M. and Mollayi, S. 2012. Enhancement of compatible solute and secondary metabolites production in Plantago ovata Forsk. by salinity stress. Journal of Medicinal Plants Research, 6(18), 3495-3500.

Harborne, J. B., Williams, C. A. 2000. Advances in flavonoid research since 1992. Phytochemistry, 55(6), 481-504.

Hartzendorf, T. and Rolletschek, H. 2001. Effects of $\mathrm{NaCl}$-salinity on amino acid and carbohydrate contents of Phragmites australis. Aquatic Botany. 69(2-4), pp. 195-208.

Hassanein, A. M. 1999. Alterations in protein and esterase patterns of peanut in response to salinity stress. Biologia plantarum, 42(2), 241-248.

Heath, R. L., Packer, L. 1968. Photoperoxidation in isolated chloroplasts: I. Kinetics and stoichiometry of fatty acid peroxidation. Archives of biochemistry and biophysics, 125(1), 189-198.

Hedge, J. E. , Hofreiter, B. T. 1962. In carbohydrate chemistry 17 (Eds whistler RL and Be Millee, JN) Academic press. New York.

Henson, I. E., Mahalakshmi, V., Bidinger, F. R. , Alagarswamy, G. 1981. Genotypic variation in pearl millet (Pennisetum americanum L. Leeke), in the ability to accumulate abscisic acid in response to water stress. Journal of experimental botany, 899-
910.

Horwitz, W., Chichilo, P. ,Reynolds, H. 1970. Official methods of analysis of the Association of Official Analytical Chemists. Official methods of analysis of the Association of Official Analytical Chemists.

Jaremicz, Z., Luczkiewicz, M., Kisiel, M., Zárate, R., Jaber-Vazdekis, N. E., Migas, P. 2014. Multidevelopment-HPTLC Method for Quantitation of Hyoscyamine, Scopolamine and their Biosynthetic Precursors in Selected Solanaceae Plants Grown in Natural Conditions and as In vitro Cultures. Phytochemical Analysis, 25(1), 29-35.

Johansen, D. A. 1940. Plant microtechique. McGraw-Hill Book Company, Inc.; London, 523p.

Karawya, M. S., Abdel-Wahab, S. M., Hifnawy, M. S., \& Ghourab, M. G. (1975). Colorimetric and gasliquid chromatographic determination of atropinehyoscyamine and hyoscine (scopolamine) in solanaceous plants. Journal-Association of Official Analytical Chemists, 58(5), 884-887.

Kennedy, B. ,De Filippis, L. F. 1999. Physiological and oxidative response to $\mathrm{NaCl}$ of the salt tolerant Grevillea ilicifolia and the salt sensitive Grevillea arenaria. Journal of plant physiology, 155(6), 746754.

Khavari-Nejad, R. A. , Mostofi, Y. 1998. Effects of $\mathrm{NaCl}$ on photosynthetic pigments, saccharides, and chloroplast ultrastructure in leaves of tomato cultivars. Photosynthetica, 35(1), 151-154.

Kocisko, D. A., Come, J. H., Priola, S. A., Chesebro, B., Raymond, G. J., Lansbury, P. T. , Caughey, B. 1994. Cell-free formation of proteaseresistant prion protein. Nature, 370(6489), 471.

Kumar, N., Pamidimarri, S. D., Kaur, M., Boricha, G. , Reddy, M. P. 2008. Effects of $\mathrm{NaCl}$ on growth, ion accumulation, protein, proline contents and antioxidant enzymes activity in callus cultures of Jatropha curcas. Biologia, 63(3), 378.

Laemmli, U. K. 1970. Cleavage of structural proteins during the assembly of the head of bacteriophage T4. Nature, 227(5259), 680.

Lange, H., Shropshire, W., Mohr, H. 1971. An analysis of phytochrome-mediated anthocyanin synthesis. Plant Physiology, 47(5), 649-655.

LaRosa, P. C., Singh, N. K., Hasegawa, P. M. , 
Bressan, R. A. 1989. Stable $\mathrm{NaCl}$ tolerance of tobacco cells is associated with enhanced accumulation of osmotin. Plant Physiology, 91(3),855-861.

Mahajan, S. ,Tuteja, N. 2005. Cold, salinity and drought stresses: an overview. Archives of biochemistry and biophysics, 444(2), 139-158.

Mansour, M. M. F. 2000. Nitrogen containing compounds and adaptation of plants to salinity stress. Biologia Plantarum, 43(4), 491-500.

Martìnez, J. P., Lutts, S., Schanck, A., Bajji, M. , Kinet, J. M. 2004. Is osmotic adjustment required for water stress resistance in the Mediterranean shrub Atriplex halimus L. Journal of Plant Physiology, 161(9), 1041-1051.

M-STAT. 1990. A Microcomputer program for the design management and analysis of agronomic research experiments. Michigan state university.

Munir, N. , Aftab, F. 2013. Changes in activities of antioxidant enzymes in response to $\mathrm{NaCl}$ stress in callus cultures and regenerated plants of sugarcane. Journal of Animal and Plant Sciences, 23(1), pp. 203-209.

Naik, P. M. ,Al-Khayri, J. M. 2016. Impact of abiotic elicitors on in vitro production of plant secondary metabolites: a review. Journal of advanced Research in Biotechnology, 1(2), 7.

Namdeo, A. G. 2007. Plant cell elicitation for production of secondary metabolites: a review. Pharmacognosy Review, 1(1), 69-79.

Ni, J., Yang, X., Zhu, J., Liu, Z., Ni, Y., Wu, H. , Liu, T. 2015. Salinity-induced metabolic profile changes in Nitraria tangutorum Bobr. suspension cells. Plant Cell, Tissue and Organ Culture (PCTOC), 122(1), 239-248.

Queirós, F., Rodrigues, J. A., Almeida, J. M., Almeida, D. P., Fidalgo, F. 2011. Differential responses of the antioxidant defence system and ultrastructure in a salt-adapted potato cell line. Plant Physiology and Biochemistry, 49(12), 1410-1419.

Rao, G.G., Rao, G.R. 1981. Pigment composition \& chlorophyllase activity in pigeon pea (Cajanus indicus Spreng) \& Gingelley (Sesamum indicum L.) under $\mathrm{NaCl}$ salinity. Indian Journal of Experimental Biology, (19), 768-770.

Rosen, H. 1957. A modified ninhydrin colorimetric analysis for amino acids. Archives of biochemistry and biophysics, 67(1), 10-15.

Sajid Aqeel Ahmad, M., Javed, F. , Ashraf, M. 2007. Iso-osmotic effect of $\mathrm{NaCl}$ and PEG on growth, cations and free proline accumulation in callus tissue of two indica rice (Oryza sativa L.) genotypes. Plant growth regulation, 53(1), pp. 5363.

Sass, J.E. 1961. Botanical Microtechnique.Third edition.The IOWA State University Press.Amess. Iowa.

Selmar, D. 2008. Potential of salt and drought stress to increase pharmaceutical significant secondary compounds in plants. Landbauforschung Volkenrode, 58(1-2), pp. 139-144.

Sen, A. , Alikamanoglu, S. 2011. Effect of salt stress on growth parameters and antioxidant enzymes of different wheat (Triticum Aestivum L .) varieties on in vitro tissue culture. Fresenius Environmental Bulletin, 20(2), 489-495.

Sharma, V. , Ramawat, K. G. 2014. Salt stress enhanced antioxidant response in callus of three halophytes (Salsola baryosma, Trianthema triquetra, Zygophyllum simplex) of Thar Desert. Biologia (Poland), 69(2), 178-185.

Shi, Q., Ding, F., Wang, X. , Wei, M. 2007. Exogenous nitric oxide protect cucumber roots against oxidative stress induced by salt stress. Plant physiology and biochemistry, 45(8), 542-550.

Singh, N. K., Bracker, C. A., Hasegawa, P. M., Handa, A. K., Buckel, S., Hermodson, M. A. , Bressan, R. A. 1987. Characterization of osmotin: a thaumatin-like protein associated with osmotic adaptation in plant cells. Plant physiology, 85(2), 529-536.

Steel, R. G. D., Torrie, J. H. ,Dickey, D. A. 1997. Principles and procedures of statistics: a biometrical approach., 3rd ed. (McGraw-Hill: New York).

Steyn, W. J., Wand, S. J. E., Holcroft, D. M. ,Jacobs, G. 2002. Anthocyanins in vegetative tissues: a proposed unified function in photoprotection. New Phytologist, 155(3), 349-361.

Sun, B., Jing, Y., Chen, K., Song, L., Chen, F., Zhang, L. 2007. Protective effect of nitric oxide on iron deficiency-induced oxidative stress in maize (Zea mays). Journal of plant physiology, 164(5), 536-543. 
Tackholm, V. 1974. Students flora of Egypt. 2nd Ed. Cairo University, Cairo, 888p.

Takahama, U., Oniki, T. 1997. A peroxidase/phenolics/ascorbate system can scavenge hydrogen peroxide in plant cells. Physiologia Plantarum, 101(4), 845-852.

Urbanek, H., Kuzniak-Gebarowska, E., Herka, K. 1991. Elicitation of defence responses in bean leaves by Botrytis cinerea polygalacturonase. Acta Physiologie Plantarum (Poland),13:43-50.

Vanishree M., Lee C.Y., Lo S.F., Nalawade SM, Lin C.Y. , Tsay S.H. 2004. Studies on the production of some important metabolites from medicinal plants by plant tissue cultures. Botanical Academic Science 45: 1-22.

Wang, L., Burhenne, K., Kristensen, B. K. , Rasmussen, S. K. 2004. Purification and cloning of a Chinese red radish peroxidase that metabolise pelargonidin and forms a gene family in Brassicaceae. Gene, 343(2), 323-335.

Winkel-Shirley, B. 2002. Biosynthesis of flavonoids and effects of stress. Current opinion in plant biology, 5(3), 218-223.

Yamasaki, H., Sakihama, Y., Ikehara, N. 1997. Flavonoid-peroxidase reaction as a detoxification mechanism of plant cells against $\mathrm{H}_{2} \mathrm{O}_{2}$. Plant Physiology, 115(4), 1405-1412. 